\title{
De transitie en transformatie van zorg voor jeugd: een ruwe diamant
}

Frans Pijpers ${ }^{1}$ Magda Boere-Boonekamp ${ }^{1}$ Leanthe van Harten ${ }^{1}$ Loes Hartman ${ }^{1}$ Paul Kocken ${ }^{1}$ Brigit Rijbroek ${ }^{1}$ Arielle de Ruijter ${ }^{1}$ Toon $_{\text {Voorham }}{ }^{1}$

Als gevolg van tekortkomingen in de zorgstructuur vindt een bestuurlijke transitie van het stelsel van zorg voor jeugd en een zorginhoudelijke transformatie plaats. De verplichte Jeugdbescherming, de vrijwillige Jeugdzorg, Jeugdgezondheidszorg, Jeugd-GGZ, Jeugd-LVB (licht verstandelijk beperkten) en welzijn komen in één bestuurlijk kader, waarover de gemeenten, soms op bovengemeentelijk niveau, het beleid bepalen. Voor gemeenten wordt de samenhang tussen het algemene preventief jeugdbeleid, de jeugdgezondheidszorg en de jeugdzorg erg belangrijk, en de Centra voor Jeugd en Gezin vervullen daarin de verbindende schakel.

Er zijn onzekerheden over de toekomst. De 408 gemeenten moeten straks voorzien in een kwalitatief en kwantitatief toereikend aanbod van jeugdhulp. Ze moeten adviseren over het bepalen en inzetten van de aangewezen vorm van jeugdhulp en een verzoek doen tot onderzoek bij de Raad voor de Kinderbescherming als een kinderbeschermingsmaatregel nodig is. Hiermee is op lokaal niveau weinig ervaring. Dit vraagt om weloverwogen besluitvorming op de weg naar de invoering van het nieuwe jeugdstelsel. Vermeiren stelt in zijn bijdrage dan ook kritische vragen over de toekomstige zorg: krijgen kinderen wel de zorg die zij nodig hebben, als de gemeente bepaalt welke zorg dat is? Knorth en Reijneveld becommentariëren het vermogen van de zorg om tot een goede inschatting te komen van de kindveiligheid, gezien de uiteenlopende ervaring en diagnostische vaardigheden van professionals. Hebben professionals de goede methodieken om zorgbehoeften te signaleren en om ouders te motiveren om gebruik te maken van de zorg? Zorgen over het jeugdstelsel gelden ook voor het voortraject, wanneer de JGZ aan zet is. Doove, Heller en Feran pleiten voor een integrale blik, preventieve en gepersonaliseerde zorg. Strijthagen stelt dat JGZ de verbinder in het sociale domein zou kunnen zijn. Nog veel vragen. Witte wijst daarom op het belang van actieonderzoek door praktijk, onderwijs en onderzoek gezamenlijk. En Zandbergen geeft aan dat co-creatie met ouders en jeugdigen goede innovatieve ideeën oplevert. Dannenberg wijst op de beleidsruimte die naar zijn idee gemeenten nodig hebben om maatwerk te kunnen leveren. De transitie en transformatie is geen blauwdruk, maar vraagt om een ontwikkelingsbenadering. De zorg voor jeugd zal als een ruwe diamant zorgvuldig geslepen moeten worden.

themaredactie (preventieve) zorg voor de jeugd

\section{Oude wijn in 408 nieuwe vaten}

Robert Vermeiren ${ }^{1}$

20-12-2012 een prachtige dag, de geboorte van mijn zoon. Een gezond kereltje is het. We doen er uiteraard alles aan om dat zo te houden. Met gezonde voeding, een liefdevolle duidelijke opvoeding, ... nemen we onze verantwoordelijkheid hem gezond en veilig te laten opgroeien. Zoals de overheid het van ons wil.

Maar stel dat het ondanks alles toch anders gaat. Stel dat dit unieke wezentje het thuis en op school niet blijkt te doen Stel dat hij psychische problemen krijgt.

Dan zouden we hulp zoeken uiteraard. Hoe dat zal verlopen is anders als de jeugdwet er is.

$\mathrm{Nu}$ zouden we wellicht onze huisarts raadplegen. Om verwezen te worden. Voor GGZ zijn we verzekerd, in onze polis staat wat kan. Op voorhand weten we dus waar we aanspraak op kunnen maken. Als we dat anders willen, dan kunnen we ons

1 VUMC, Amsterdam volgend jaar extra verzekeren, en zo nodig veranderen van verzekeraar.

\section{NA 2015}

Met de jeugdwet gaat dat drastisch veranderen. Vanaf 2015 zijn we niet langer verzekerd voor zorg bij psychische problemen van ons kind. Psychische problemen vallen dan onder de noemer jeugdhulp. Vanaf dan bepaalt de gemeente welke zorg onze zoon kan krijgen.

De reden zoals de Memorie van toelichting bij de jeugdwet het verwoordt: 'De afgelopen decennia zijn steeds meer ongemakken en problemen het medische circuit in getrokken'. 'Het is een doorgeschoten tendens om sociale problemen op te lossen onder het medische regime.' Gegeven het feit dat slechts $1 / 5$ van alle jeugdzorg gelden aan de medische GGZ worden besteedt, een bijzonder uitgangspunt.

Alle zorg voor jeugd, inclusief de kinderpsychiatrie, wordt 